\title{
NEW MICRO-CADDISFLIES FROM THE SOUTHEASTERN UNITED STATES (TRICHOPTERA : HYDROPTILIDAE)
}

\author{
RALPH W. Holzenthal AND ROBERT W. KeLley \\ Department of Entomology, Fisheries, and Wildlife \\ Clemson University, Clemson, SC 29631 USA
}

\begin{abstract}
Males of 6 new species of Hydroptilidae (Trichoptera) from the southeastern United States are described and illustrated: Hydroptila carolae n.sp. from South Carolina, $H$. disgalera n.sp. from Alabama and South Carolina, $H$. ouachita n.sp. from Louisiana, $H$. poirrieri n.sp. from Louisiana and Mississippi, $H$. tridentata n.sp. from South Carolina, and Oxyethira kingi n.sp. from Florida.
\end{abstract}

\section{RESUMEN}

Se describen y se ilustran los machos de seis especies nuevas de $\mathrm{Hy}$ droptilidae (Trichoptera) del sudeste de los Estados Unidos: Hydroptila carolae sp. nov. de Carolina del Sur, $H$. disgalera sp. nov. de Alabama y Carolina del Sur, $H$. ouachita sp. nov. de Louisiana, $H$. poirrieri sp. nov. de Louisiana y Mississippi, $H$. tridentata sp. nov. de Carolina del Sur, y Oxyethira kingi sp. nov. de Florida.

The southeastern United States contains a great variety of microcaddisflies. More than 90 species in 12 genera are known to occur in this region and additional collecting will undoubtedly reveal many new species. Recent regional faunal summaries have reported 16 species of Hydroptilidae from Arkansas (Unzicker et al. 1970), 35 species from Florida (Blickle 1962; Harris, Lago, and Scheiring 1982), 28 species from Louisiana and Mississippi (Harris, Lago, and Holzenthal 1982), 49 species from North and South Carolina (Unzicker et al. 1982), 38 species from Tennessee (Etnier and Schuster 1979), and 40 species from Virginia (Parker and Voshell 1981). Kelley and Morse (1982) provided distributional information for 23 species of Oxyethira occurring in the Southeast. In this paper we describe males of 6 new species of Hydroptilidae from the coastal plains of Alabama, Florida, Louisiana, Mississippi and South Carolina.

Terminology for genitalic structures generally follows that of Marshall (1979) with the following modification. We prefer the term "subgenital process" over Marshall's "subgenital plate." In the Hydroptila consimilis group this structure appears to originate laterally from segment IX and is sclerotized primarily along its margin, with a pair of distal setae. It may be homologous to the subgenital processes of Oxyethira which may be parallel, convergent or apically fused (Kelley 1982).

Abbreviations for genitalic structures in Fig. 1-6 apply to the following terms : ap.: apodeme; b.p.: bilobed process; inf.: inferior appendages; int.: intermediate appendages; par.: paramere; spb.: subgenital process; s.p.: sternal process of abdominal segment VII; VII, VIII, IX, X: terminal abdominal segments 7-10, respectively. A, B, and C in Fig. 1-6 are lateral, dorsal and ventral views respectively. $\mathrm{D}$ is a dorsal view of the phallus. 


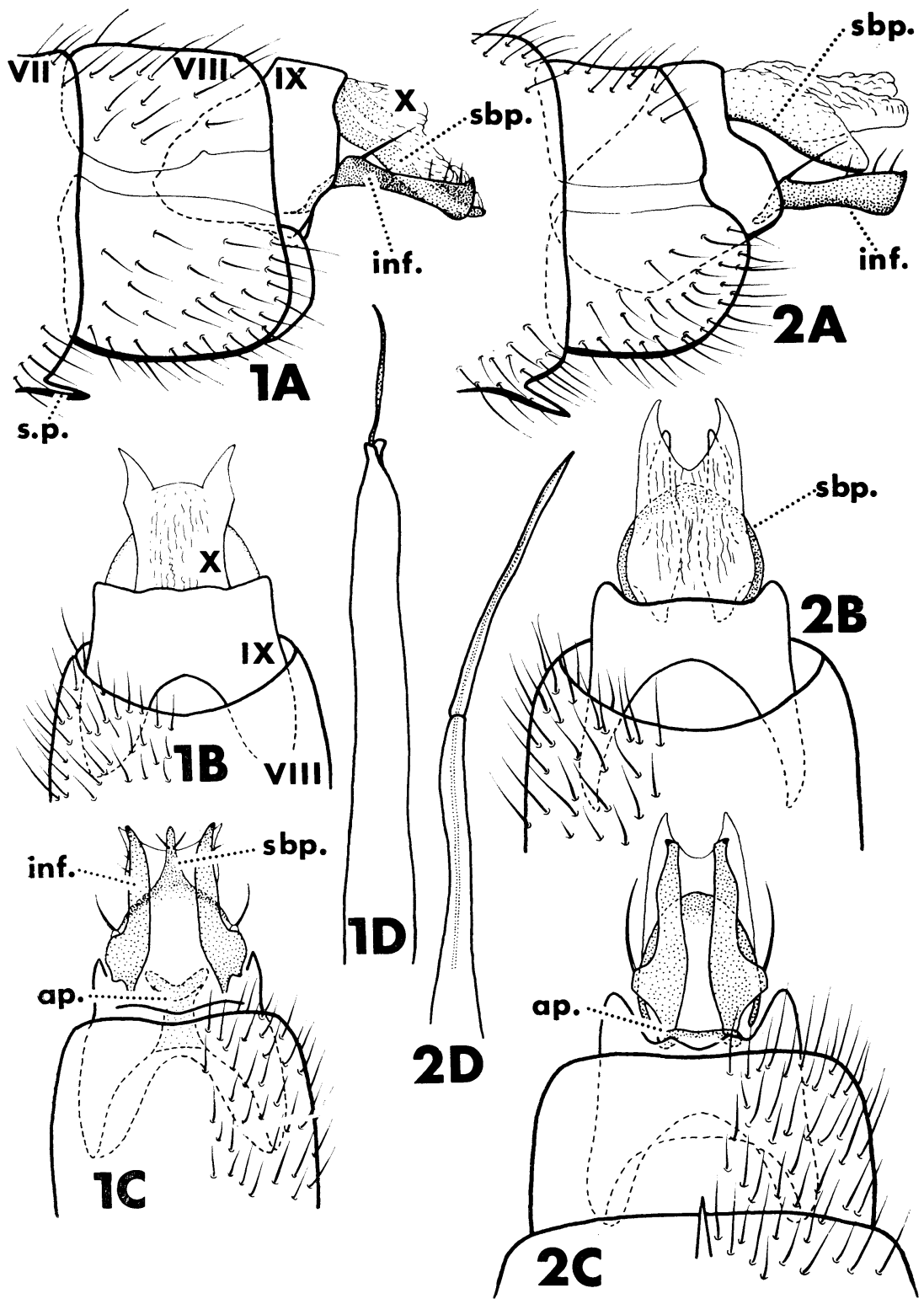

Fig. 1-2. Male genitalia of Hydroptila n. spp. $1, H$. carolae n. sp.; $2, H$. disgalera n. sp. See text for abbreviations.

Types will be deposited in the National Museum of Natural History, Smithsonian Institution (USNM), the Illinois Natural History Survey (INHS), the Florida State Collection of Arthropods (FSCA) and the Clemson University Insect Museum (CLEM) as indicated below. 


\section{Hydroptila carolae Holzenthal \& Kelley, New SPECIES}

Fig. 1A-D

Hydroptila sp. 3, Morse et al. 1980, p. 91.

This species, a member of the $H$. consimilis group of Marshall (1979), is remarkably similar to $H$. quinola Ross in overall plan of the genitalia, but differs greatly from that species in the structure of the phallus. In $H$. quinola the phallus is thin and tapered to its apex. In the new species the phallus is very long with a tubular basal portion and a thin stylet-like apical portion.

MALE: Length $3.5 \mathrm{~mm}$. Brown in alcohol. Antennae 30-segmented. Abdominal segment VII with sternal process (s.p.). Segment VIII quadrate in lateral view; heavily setose. Segment IX half width of VIII and extending anteriorly into that segment; with a large meso-ventral apodeme (ap.). Segment $\mathrm{X}$ largely membranous; in dorsal view with pair of diverging apico-lateral extensions. Subgenital process $(s b p$.$) as long as inferior ap-$ pendages (inf.); in ventral view, evenly rounded baso-laterally, tapering to a sharp apical projection bearing 2 divergent subapical setae. Inferior appendages (inf.) well separated basally, short; in lateral view, somewhat club-shaped, narrowest in middle; apico-dorsal corner pointed; apico-ventral corner rounded; each with a single large baso-dorsal seta and 2-3 small subapico-dorsal setae. Phallus long, extending anteriorly into segment VI; basal portion tubular, apical portion thin and stylet-like; paramere absent. HolotyPE: $\hat{\delta}$, South Carolina: Aiken Co.: Savannah River Plant, Upper Three Runs Creek at SRP road 8-1, 18-X-1980, col. R. W. Kelley, R. W. Holzenthal (USNM).

PARATYPes: Same data as holotype, 4-IX-1976, 4 of, col. D. Herlong, S. Prichard (CLEM) ; same, 29-III-1977, 18 o (INHS); same, 17-V-1977, 1 of (CLEM) ; same, 1-IX-1979, 1 of col. R. W. Kelley, E. McEwan (FSCA). Eтy Mology: Named in honor of the junior author's wife, Carol.

DisTRIBUTION: Thus far known only from the type locality.

\section{Hydroptila disgalera Holzenthal \& Kelley, NEw SPECIES}

Fig. 2A-D

Hydroptila quinola Ross ?, Morse et al. 1980 p. 91.

This is also a $H$. consimilis group species similar in general appearance to $H$. quinola Ross. It differs most strikingly from that species and the previous one in the shape of the subgenital process. In ventral view, this process is acuminated in $H$. quinola and evenly rounded in $H$. disgalera. Its phallus is almost identical to that of $H$. quinola. Most males of this species lack the elaborate cephalic scent caps typical of the genus.

MALE: Length $2.6 \mathrm{~mm}$. Brown in alcohol. Antennae 30-segmented. Abdominal segment VII with sternal process. Segment VIII somewhat quadrate in lateral view, tergum slightly shorter than sternum; heavily setose. Segment IX $3 / 4$ width of VIII, with a small meso-ventral apodeme (ap.). Segment $\mathrm{X}$ largely membranous; in dorsal view with pair of converging to parallel apico-lateral extensions. Subgenital process $(s b p$.) semi-circular in ventral view. Inferior appendages (inf.) well separated basally, short; in lateral view with dorsal and ventral edges slightly sinuate and gradually expanded apically; apico-dorsal corner pointed; apico-ventral corner rounded; each with a single large baso-dorsal seta and 2-3 small subapico- 


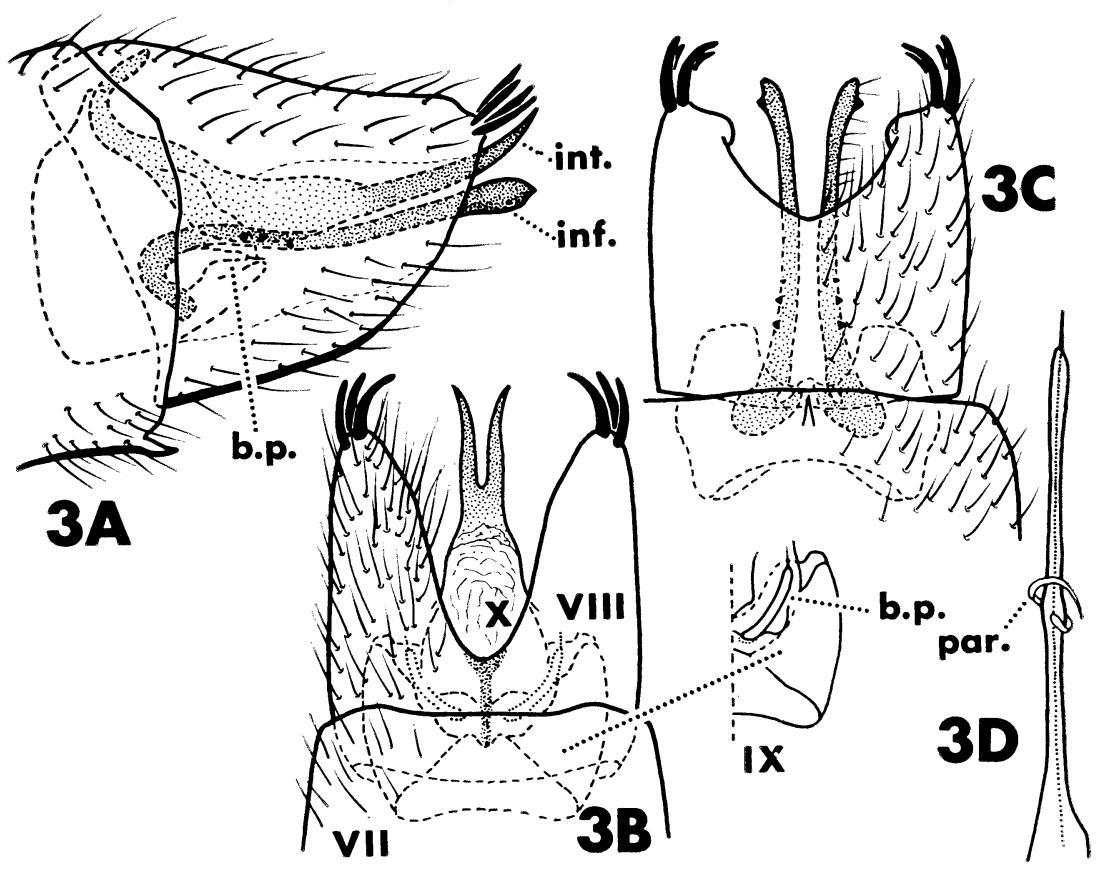
tions.

Fig. 3. Male genitalia of Hydroptila ouachita n. sp. See text for abbrevia-

dorsal setae. Phallus long; basal portion simple and slender, apical portion tapered to apex; paramere absent.

HolotyPe: ô, South Carolina: Aiken Co.: Savannah River Plant, Upper Three Runs Creek at SRP road 8-1, 11-V-1979, col. R. W. Kelley, E. McEwan (USNM).

PARATyPes: Same data as holotype, 4-IX-1976, 2 ô, col. D. Herlong, S. Prichard (USNM) ; same, 29-III-1977, 21 ô (INHS) ; same, 3-V-1977, 7 ô (INHS); same, 17-V-1977, 8 ô (FSCA); same, 8-VIII-1977, 1 oै (FSCA) ; same, 12-IV-1979, 2 ô, col. R. W. Kelley, E. McEwan (CLEM); same, 11-VI-1979, 1 ô (CLEM); same, 6-VIII-1979, 2 ô (CLEM); same, 1-IX-1979, 1 ô (CLEM); same, 20-VIII-1980, 1 ô (CLEM); Alabama: Mobile Co.: Cedar Creek at Indian Grave Creek, 12-V-1982, 1 ô, col. S. C. Harris, P. O'Neil (FSCA) ; Indian Grave Creek E of Citronelle, 29-IX-1981, 31 ô, col. S. C. Harris, P. O'Neil (INHS); Little Creek, 4 miles SE Citronelle, 29-IX-1981, 2 ô, col. S. C. Harris, P. O'Neil (USNM) ; Perry Co.: Oakmulgee Creek at Hwy 30, 20-IX-1981, 1 ô, col. S. C. Harris, P. O'Neil (CLEM).

ETYMOLOGY: Latin for "without cap" in reference to the absence of cephalic scent caps in most males of the species.

Distribution: Common and widely distributed in southern Alabama. In South Carolina known only from the type locality. 


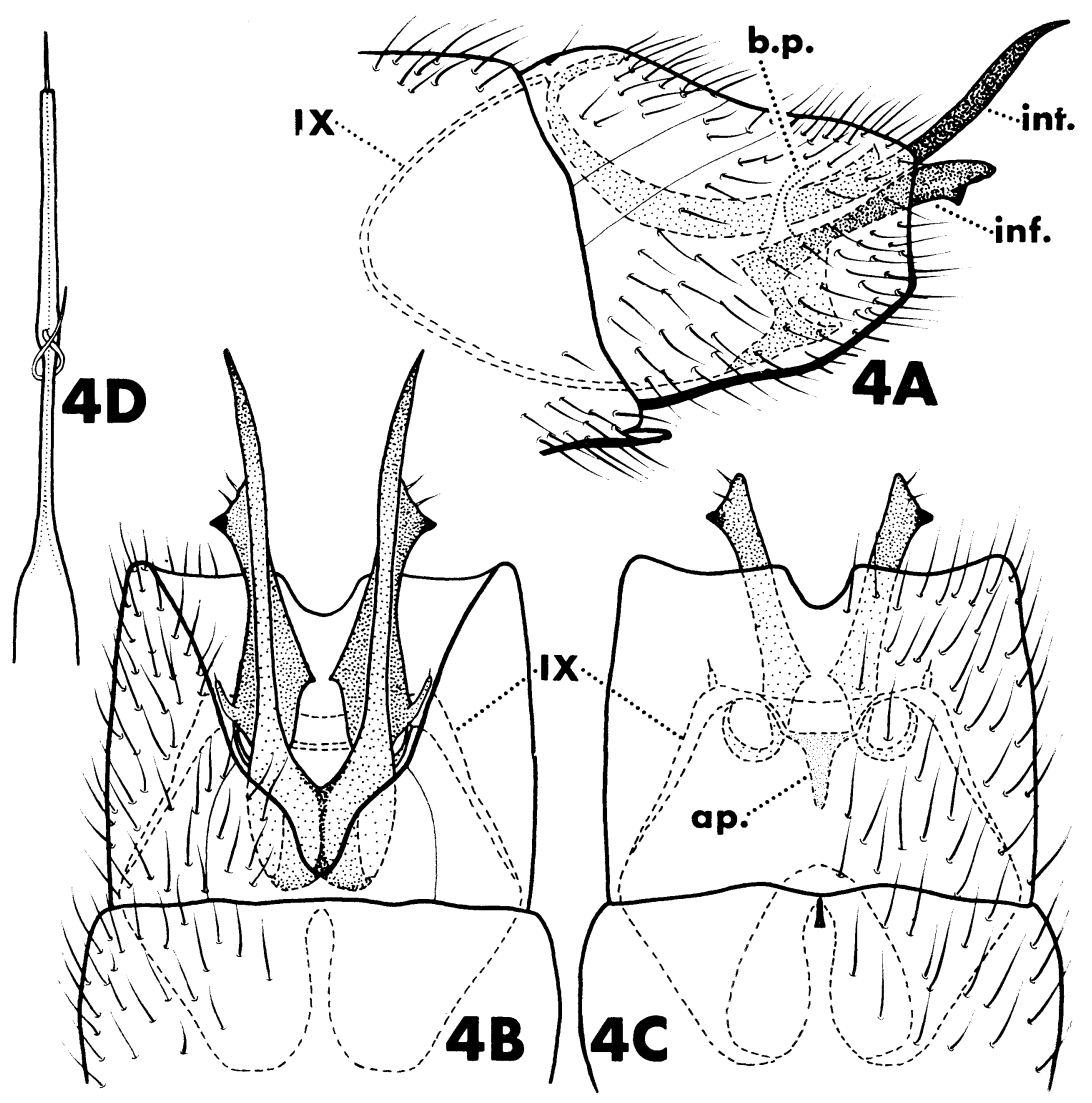
tions.

Fig. 4. Male genitalia of Hydroptila poirrieri n. sp. See text for abbrevia-

\section{Hydroptila ouachita Holzenthal \& Kelley, New Species \\ Fig. 3A-D, inset}

Although superficially resembling $H$. acadia Ross, a member of the $H$. waubesiana group of Marshall (1979), this species is easily distinguished from other species by its possession of long saber-like intermediate appendages and by the presence of 3 dark sclerotized points in the basal region of the inferior appendages.

MALE: Length $2.5 \mathrm{~mm}$. Brown in alcohol. Antennae 28-segmented. Abdominal segment VII with sternal process. Segment VIII in lateral view somewhat triangular, longer than wide and with dorsal margin straight and ventral margin curved; apico-dorsal corner bearing 4 heavy, black, mesally directed spines; in dorsal view with a deep, broad, V-shaped mesal excision, ventrally with a shallower mesal excision; heavily setose. Segment IX short, completely retracted within VIII; dorsally reduced to narrow bridge. Segment X long; lightly sclerotized basally; with a pair of saber-like inter- 
mediate appendages (int.). Inferior appendages (inf.) close together basally; long, extending beyond posterior margin of VIII; in lateral view narrow, shaped like a shepherd's crook; each with 3 dark sclerotized points just before midlength and a single dark subapical point; bilobed process (b.p.) present. Phallus long and narrow; with a spiralled paramere (par.) at midlength; ejaculatory duct protruding at apex.

HoLotyPE: ô, Louisiana: Jackson Parish: Schoolhouse Spring, T17N, R1W, Sec 12. 30-III-1973, col. J. C. Morse (USNM).

Paratypes: Same data as holotype, 5 o (INHS) ; same, 24-VIII-1973, $6 \hat{\delta}$, col. J. C. Morse, J. Louton (CLEM).

ETYMOLOGY: Named for the Ouachita River.

DISTRIBUTION : Known only from the type locality, a small artesian spring.

\section{Hydroptila poirrieri Holzenthal \& Kelley, New SPECIES}

Fig. 4A-D

Hydroptila n.sp., Harris, Lago, and Holzenthal 1982 p. 510.

Another member of the $H$. waubesiana group, this species resembles $H$. ouachita n.sp. in general plan of the intermediate appendages and phallus, but can be distinguished readily from that species by the absence of the heavy black spines of segment VIII.

MALE: Length $2.3 \mathrm{~mm}$. Brown in alcohol. Antennae 27-segmented. Abdominal segment VII with sternal process. Segment VIII roughly trapezoidal in lateral view, posterior margin about half width of anterior margin; in dorsal view with a deep broad V-shaped mesal excision; ventrally with a much smaller U-shaped mesal excision; heavily setose. Segment IX completely retracted within VII and VIII; hexagonal-shaped in dorsal and ventral views, with a narrow meso-dorsal excision and a meso-ventral apodeme $(a p$.$) . Segment \mathrm{X}$ apparently reduced to a pair of extremely long, thin, sickle-shaped intermediate appendages (int.) extending well beyond posterior margin of VIII. Inferior appendages (inf.) close together basally, short, finger-shaped in lateral view; each with a subapical, ventro-lateral dark point; basal region ring-shaped when viewed ventrally; bilobed process (b.p.) present. Phallus long; widest basally, markedly narrow and parallelsided between base and paramere, apex beyond paramere slightly enlarged; paramere present at midlength and spiralled once completely around phallus; ejaculatory duct protruding at apex.

HolotyPe: ô, Mississippi: Clarke Co.: Chunky Creek at dirt road, $7.1 \mathrm{~km}$. NW of Hwy. 11 in Enterprise, 13-X-1979, col. R. W. Holzenthal (USNM). Paratypes: Louisiana: Tangipahoa Parish: Big Creek, approx. $3 \mathrm{mi}$. E of Amite, 24-IV-1976, 1 of , col. M. E. Dakin (USNM); Mississippi: Amite Co.: West Fork Amite River at unmarked gravel road, 14.5 air $\mathrm{km}$. SSW of Liberty, 28-V-1979, 2 o, col. R. W. Holzenthal (FSCA); Covington Co.: Ocatoma Creek, $0.3 \mathrm{~km}$. W of Sanford, 30-VIII-1979, 2 , col. R. W. Holzenthal (USNM); Lincoln Co.: Homochitto River at Hwy. $550,6.8 \mathrm{~km}$. W of Caseyville, 1-VIII-1979, 10 s, col. R. W. Holzenthal (CLEM) ; Pike Co.: Topisaw Creek at Hwy. 44, $0.6 \mathrm{~km}$. W of Pricedale, 29-IX-1979, 9 ô, col. R. W. Holzenthal (CLEM) ; Tishomingo Co.: Tishomingo State Park, 8-IX1980, 1 o , col. P. K. Lago (CLEM).

Eтymology: Named in honor of Dr. Michael A. Poirrier, University of New Orleans. 


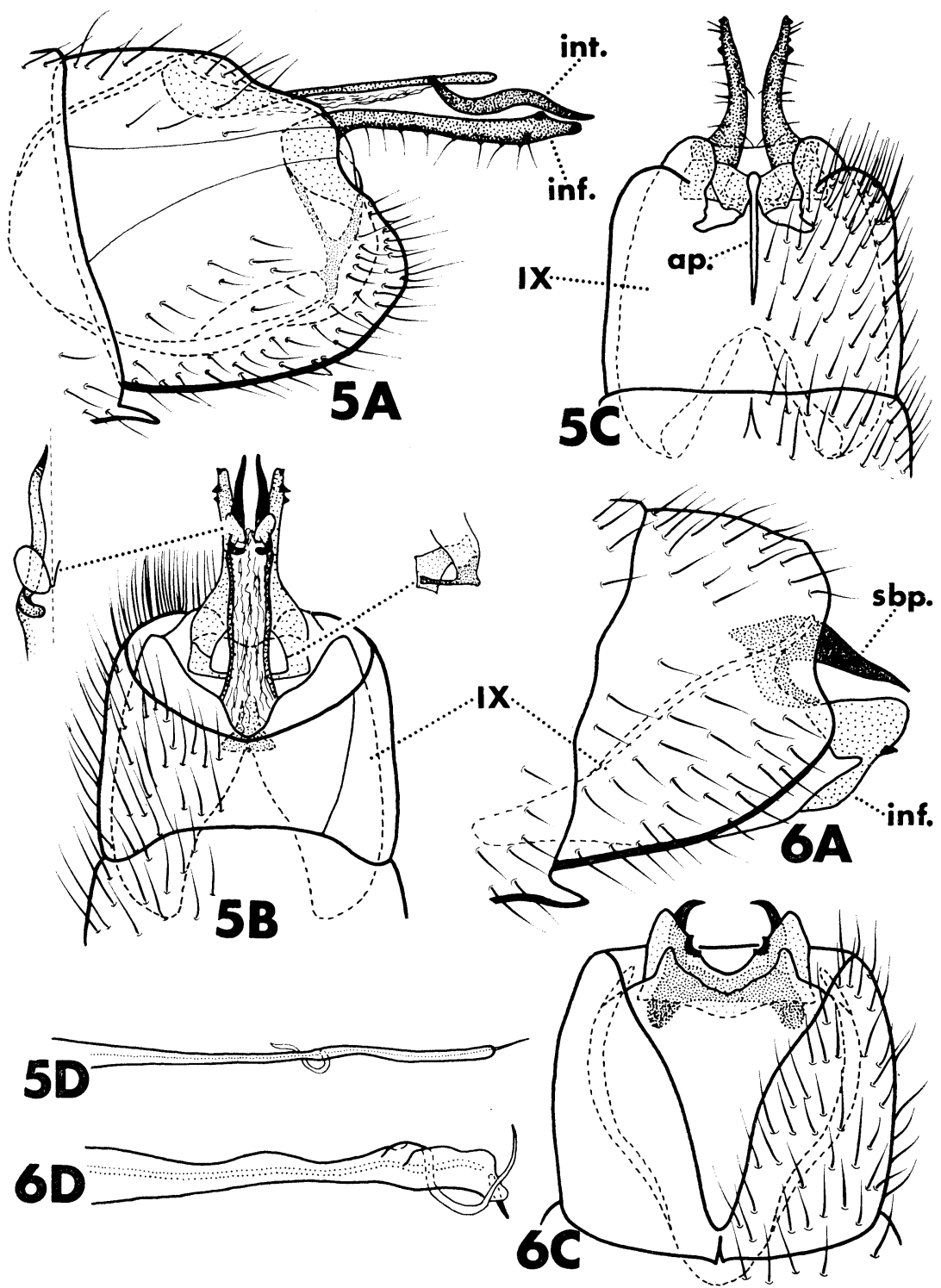

Fig. 5-6. Male genitalia of Hydroptilidae, n. spp. 5, Hydroptila tridentata n. sp.; 6, Oxyethira kingi n. sp. See text for abbreviations.

Distribution: As noted by Harris, Lago, and Holzenthal (1982) this species is common and widely distributed in southeastern Louisiana and Mississippi.

Hydroptila tridentata Holzenthal \& Kelley, New SPECIES Fig. 5A-D, insets 
This species is a member of the $H$. waubesiana group. It bears some resemblance to $H$. delineata Morton in the structure of the intermediate appendages, but the 3 prominent, dark apical points of the inferior appendges render it distinct.

MALE: Length $2.4 \mathrm{~mm}$. Brown in alcohol. Antennae 30-segmented. Abdominal segment VII with sternal process. Segment VIII somewhat angular in lateral view, posterior margin sinuate; heavily setose. Segment IX completely retracted within VIII; dorsally reduced to a very narrow bridge; with 2 ear-shaped ventro-lateral posterior projections and a meso-ventral apodeme (ap.). Segment X complicated, consisting of a basal membranous portion bounded laterally by sclerotized strips and a pair of apical, sinuate intermediate appendages (int.). Inferior appendages (inf.) basally contiguous; L-shaped in lateral view, long and thin; each with 3 prominent, dark apico-lateral points and several setae along ventral edge; complex brace-like structure basally; bilobed processes absent. Phallus long and thin; hook-shaped paramere present just beyond midlength; ejaculatory duct protruding at apex.

HolotyPe: $\hat{o}$, South Carolina: Dorchester Co.: Four Holes Swamp, Goodsons Lake, 7-V-1976, col. J. C. Morse (USNM).

PARATYPES: Same data as holotype, $2 \hat{\text { o }}$ (INHS); same, $3 \hat{\text { o }}$ (CLEM); South Carolina: Aiken Co.: Savannah River Plant, Tinker Creek at SRP road 8-1, 18-V-1977, 1 ô, col. D. Herlong, S. Prichard (FSCA).

ETYMology: Latin, in reference to the three dark teeth-like points on the inferior appendages.

Distribution: Known only from the localities listed in the type series.

\section{Oxyethira kingi Holzenthal \& Kelley, NEw SPECIES}

Fig. 6A, C, D

Oxyethiva n. sp. 13, Kelley 1982 p. 183, Fig. 178, ô.

This species is a member of the Oxeythira santiagensis group. Unlike other members of the group the postero-ventral processes of segment IX are short.

MALE: Length $2.6 \mathrm{~mm}$. Brown in alcohol. Number of antennal segments unknown. Abdominal segment VII with apico-mesal sternal process. Segment VIII quadrate in lateral view; in ventral view with a deep, broad, V-shaped mesal excision; heavily setose. Segment IX with dorsum lacking, ventrally produced anteriorly into segment VII; dorso-lateral edges heavily sclerotized; postero-ventral margin with 2 short processes. Segment X entirely membranous, inconspicuous upon clearing. Subgenital process $(s b p$.) sharply pointed, mesally curved at apex, not fused. Inferior appendages (inf.) triangular in shape, basally connected, with paired, dark teeth on each mesal margin. Phallus with spiralled subapical process and single apical seta.

Holotype: of, Florida: Miami, Plant Inspection Station, black light, 21-XII1964, col. J. C. Buff (65-2910) (USNM).

EтYмology: Named in honor of Dr. Edwin W. King, Professor Emeritus, Clemson University.

DisTRIBUTION : Known only from the type locality. 


\section{ACKNOWLEDGMents}

Partial funding for this research was provided by the U.S. Department of Energy's Savannah River National Environmental Research Park, the Louisiana Land and Exploration Company and the Louisiana State University Foundation. This support is gratefully acknowledged.

We are grateful to Drs. John Morse and Steve Harris for providing specimens. Mr. Steve Hamilton offered valuable assistance with various aspects of the study. Special thanks to Drs. Jewel Jordan and John Morse for critically reviewing the manuscript.

This is technical contribution No. 2170 of the South Carolina Agricultural Experiment Station, Clemson University.

We wish to thank Mrs. Donna Picard for typing the manuscript.

\section{ReFERENCES Cited}

Blickle, R. L. 1962. Hydroptilidae (Trichoptera) of Florida. Florida Ent. 45: $153-5$.

Etnier, D. A., AND G. A. Schuster. 1979. An annotated list of Trichoptera (Caddisflies) of Tennessee. J. Tennessee Acad. Sci. 54: 15-22.

Harris, S. C., P. K. Lago, and R. W. Holzenthal. 1982. An annotated list of the caddisflies (Trichoptera) of Mississippi and southeastern Louisiana. Part II: Rhyacophiloidea. Proc. Ent. Soc. Washington 84: 509-12.

, AND J. F. ScheIRING. 1982. An annotated list of Trichoptera of several streams on Elgin Air Force Base, Florida. Ent. News 93: 79-84.

Kelley, R. W. 1982. The micro-caddisfly genus Oxyethira (Trichoptera: Hydroptilidae) : Morphology, biogeography, evolution and classification. Ph.D. dissertation, Clemson University. $432 \mathrm{p}$.

- AND J. C. Morse. 1982. A key to the females of the genus Oxyethira (Trichoptera: Hydroptilidae) from the southern United States. Proc. Ent. Soc. Washington 84: 256-69.

Marshall, J. E. 1979. A review of the genera of the Hydroptilidae (Trichoptera). Bull. British Mus. (Nat. Hist.) Ent. 39: 135-239.

Morse, J. C., J. W. Chapin, D. D. Herlong, and R. S. Harvey. 1980. Aquatic insects of Upper Three Runs Creek, Savannah River Plant, South Carolina. Part I: Orders other than Diptera. J. Georgia Ent. Soc. 15: 73-101.

Parker, C. R., AND J. R. Voshell, JR. 1981. A preliminary checklist of the caddisflies (Trichoptera) of Virginia. J. Georgia Ent. Soc. 16: 1-7.

UNzicker, J. D., L. AgGuS, AND L. O. WARREN. 1970. A preliminary list of the Arkansas Trichoptera. J. Georgia Ent. Soc. 5: 167-74. , V. H. RESH, AND J. C. MoRse. 1982. Trichoptera, Chapter 9, In A. R. Brigham, W. U. Brigham, and A. Gnilka, eds., Aquatic Insects and Oligochaetes of North and South Carolina. Midwest Aquatic Enterprises, Mahomet, Illinois. 